\title{
Soil temperatures in an Atlantic high mountain environment: The Forcadona buried ice patch (Picos de Europa, NW Spain)
}

\author{
Jesús Ruiz-Fernández ${ }^{\mathrm{a}, *}$, Marc Oliva ${ }^{\mathrm{b}}$, Filip Hrbáček ${ }^{\mathrm{c}}$, Gonçalo Vieira ${ }^{\mathrm{b}}$, Cristina García-Hernández ${ }^{\mathrm{a}}$ \\ a Department of Geography, University of Oviedo, Oviedo, Spain \\ ${ }^{\mathrm{b}}$ Centre for Geographical Studies, Institute of Geography and Spatial Planning, Universidade de Lisboa, Lisbon, Portugal \\ c Department of Geography, Masaryk University, Brno, Czech Republic
}

\section{A R T I C L E I N F O}

Article history:

Received 15 February 2016

Received in revised form 13 June 2016

Accepted 27 June 2016

Available online 1 August 2016

\section{Keywords:}

Soil temperatures

Cirque wall temperatures

Thermal regimes

Freeze-thaw days

Snow

\begin{abstract}
A B S T R A C T
The present study focuses on the analysis of the ground and near-rock surface air thermal conditions at the Forcadona glacial cirque (2227 m a.s.l.) located in the Western Massif of the Picos de Europa, Spain. Temperatures have been monitored in three distinct geomorphological and topographical sites in the Forcadona area over the period 2006-11. The Forcadona buried ice patch is the remnant of a Little Ice Age glacier located in the bottom of a glacial cirque. Its location in a deep cirque determines abundant snow accumulation, with snow cover between 8 and 12 months. The presence of snow favours stable soil temperatures and geomorphic stability. Similarly to other Cantabrian Mountains, the annual thermal regime of the soil is defined by two seasonal periods (continuous thaw with daily oscillations and isothermal regime), as well as two short transition periods. However, the results showed evidence of a significantly different annual thermal regime at the ground and near-rock surface air. Relatively stable soil thermal regimes were observed at the moraine and talus sites, while a more dynamic pattern was recorded at the rock wall site. Here, a higher interannual variability in the number of freeze-thaw days was also detected, which showed evidence of the important role of the snow cover as a ground surface insulator in the area. Seasonal frost conditions are widespread today in the high lands of the massif. No permafrost regime was detected in the area, though mean temperatures measured at $0.5 \mathrm{~m}$ depth at the Forcadona buried ice patch during $2006-07\left(0.1^{\circ} \mathrm{C}\right)$ suggest that permanent negative values may be reached at deeper layers.
\end{abstract}

(c) 2016 Elsevier B.V. All rights reserved.

\section{Introduction}

Soil temperatures play a key control on geomorphological processes occurring in periglacial environments. In mid-latitude mountain regions such is the case of Iberian mountains, periglacial processes are confined today to the highest elevations and encompass a limited surface above 2000-2500 m (Oliva et al., 2016b). In these areas, snow cover is one of the factors that strongly influence the soil thermal regime and associated periglacial activity (Edwards et al., 2007). The duration and thickness of the snow cover influences both geomorphological and biological processes, but also socio-economic activities in the mountains as well as in neighbouring areas. During the cold season water is stored in the form of snow in the highlands of the mountains and limits geomorphic activity. Moreover, it also insulates the ground from the atmosphere (Ishikawa, 2003; Zhang, 2005; Frauenfeld et al., 2007). When snow melts, geomorphic activity intensifies. Such is the case of the mountains of Iberia, where periglacial dynamics is especially effective during the snow melting period when the ground can still be frozen and high

\footnotetext{
* Corresponding author at: Department of Geography, University of Oviedo, Teniente Alfonso Martínez s/n, 33011 Oviedo, Spain.

E-mail address: ruizjesus@uniovi.es (J. Ruiz-Fernández).
}

water availability enhances erosion and mass-wasting processes (Oliva et al., 2009, 2014a).

Research on the ground thermal regime in Iberian mountains has been intense during the last years in the highest mountains ranges. Permafrost conditions have been only detected in the highest areas in the Pyrenees (Serrano et al., 2001, 2006; Lugon et al., 2004; González García et al., 2016), as well as in Sierra Nevada where permafrost is spatially limited to the areas which hosted a glacier during the Little Ice Age (Gómez-Ortiz et al., 2014; Oliva et al., 2016a, 2016b). In other mountain environments seasonal frost conditions have been detected, as it is the case of the Galician ranges (Carrera and Valcárcel, 2010), Iberian Central Range (Andrés and Palacios, 2010) or Serra da Estrela (Vieira et al., 2003).

In the case of the Cantabrian Mountains, there has been a substantial advance on the knowledge of present-day periglacial dynamics over the last decades (e.g. Castañón and Frochoso, 1994, 1998; González-Gutiérrez, 2002; Serrano and González-Trueba, 2004; González-Trueba, 2007a; Rodríguez-Pérez, 1995, 2009; Santos-González, 2010; Pellitero, 2012; Ruiz-Fernández, 2013; Ruiz-Fernández et al., 2014). However, only a few studies have examined the relationship between the geomorphological setting and morphoclimatic conditions in the area (Castañón and Frochoso, 1998; Santos-González et al., 2009; González-Trueba and Serrano, 2010; 
Pellitero, 2012; Ruiz-Fernández et al., 2014; Pisabarro et al., 2015). Currently, in the summit areas of the highest massifs periglacial dynamics is active, since the remobilization of particles on the slopes is very intense, through processes such as solifluction, cryoturbation, debris flows and snow avalanches (Brosche, 1978; Castañón and Frochoso, 1994, 1998; Serrano and González-Trueba, 2004; González-Trueba and Serrano, 2010; Ruiz-Fernández et al., 2014).

In this sense, the present study focuses on the analysis of the ground thermal conditions and the near-rock surface air temperatures in the Western Massif of the Picos de Europa, one of the highest massifs of the Cantabrian Mountains. The specific purposes of this research are:

1) Characterize the interannual and intraannual variability of the ground and near-rock surface air temperatures in the last recently deglaciated environment in this massif.

2) Identify the role of snow cover on the ground thermal regime in different topographical settings, as well as its evolution during the study period.

\section{Study area}

The Picos de Europa $\left(43^{\circ} 7^{\prime} \mathrm{N}-43^{\circ} 17^{\prime} \mathrm{N}, 4^{\circ} 35^{\prime} \mathrm{W}-5^{\circ} 3^{\prime} \mathrm{W}\right)$, protected as National Park and Biosphere Reserve is the highest massif of the Cantabrian Mountains (Torrecerredo, $2648 \mathrm{~m}$ a.s.l.). These mountains located in NW Iberia are organized in three single massifs separated by deep gorges: the Western Massif or Cornión, the Central Massif or Urrieles and the Eastern Massif or Ándara. The study area of this research is included in the Western Massif (Fig. 1), the largest and second highest massif with peaks such as Peña Santa de Castilla (2596 m), Torre Santa María (2486 m), Torres del Mediu (2467 m) and Torres del Torco (2452 m).

The Picos de Europa are basically composed of Carboniferous limestones of the Griotte, Montaña and Picos de Europa formations
(Marquínez, 1989). Other Palaeozoic rocks (mainly quartzites, sandstones, shales and conglomerates), are also present in the northern and southernmost fringes of the three massifs. Limestone formations are organized in successive layers overthrusting southwards. The bedrock has been deeply shaped by fluvial erosion, intense karstic processes (Miotke, 1968; Smart, 1986; Ballesteros et al., 2015), as well as Quaternary glaciations (Frochoso and Castañón, 1998; Ruiz-Fernández et al., 2009; Moreno et al., 2010; Serrano et al., 2012; Jiménez et al., 2013). Periglacial processes are currently widespread in the highest lands of the Picos de Europa conditioned by the existence of seasonal frost and snowmelt water (Castañón and Frochoso, 1998; Serrano and González-Trueba, 2004; González-Trueba and Serrano, 2010).

Climate conditions in the Picos de Europa are typical of temperate maritime mountain environments, with annual precipitation between 1700 and $1900 \mathrm{~mm}$ in northern slopes at 700-900 $\mathrm{m}$ and exceeding $2500 \mathrm{~mm}$ in the highest elevations. In the later, precipitation mostly fall in the form of snow, and snow cover lasts for ca. 8 months as average per year (Ruiz-Fernández, 2013). In sheltered environments, longlasting snow fields persist almost throughout the year, such as in the Forcadona area. This research is precisely focused on this area where a buried ice patch is located. This site is placed at $2227 \mathrm{~m}$, between the Peña Santa de Castilla (east) and Torres del Torco (west) peaks (Fig. 1 ). It is covered by debris which protected it from solar radiation. The Forcadona buried ice patch constitutes the contemporary remnant of a cirque glacier that existed in the area during the Little Ice Age (LIA). During the LIA the Picos de Europa concentrated six glaciers, three of which were distributed in the Western Massif (González-Trueba, 2005, 2006; González-Trueba et al., 2008).

\section{Methods}

A detailed geomorphological map of the Forcadona area was prepared in September 2011 to identify the main landforms and

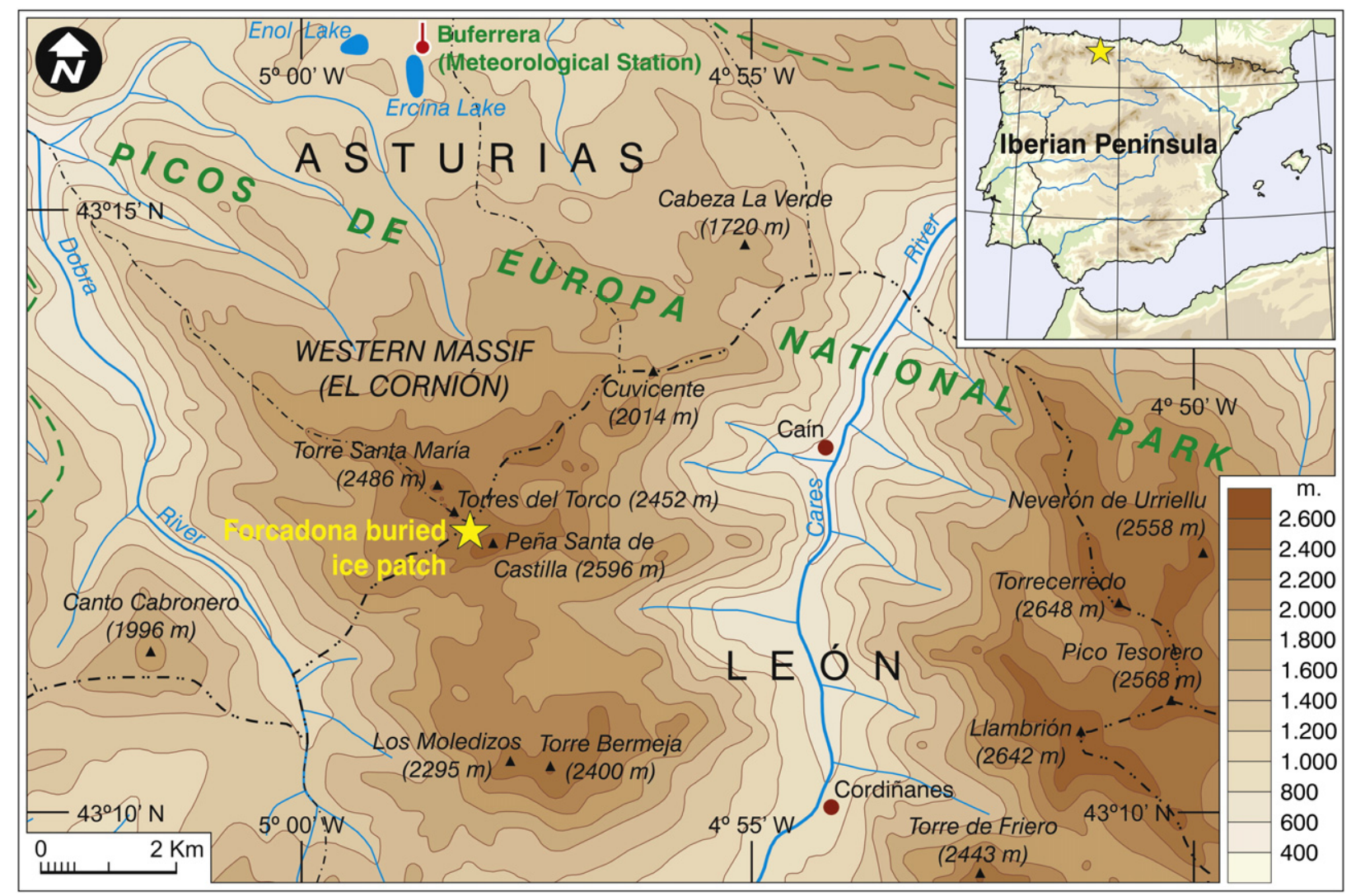

Fig. 1. Location of the Forcadona area within the Picos de Europa. 
Table 1

General characteristics of the stations examined in this research.

\begin{tabular}{|c|c|c|c|c|c|}
\hline Geomorphological setting & Depth $(\mathrm{cm}) /$ height $(\mathrm{m})$ & Altitude & Aspect & Type & Period \\
\hline Buried ice patch & $-10,-50 /-$ & 2227 & North & Ground temperature & $04 / 11 / 2006$ to $04 / 11 / 2007$ \\
\hline Talus & $-10 /-$ & 2235 & Northwest & Ground temperature & $04 / 11 / 2007$ to $07 / 08 / 2011$ \\
\hline Moraine & $-10 /-$ & 2236 & North & Ground temperature & $04 / 11 / 2007$ to $24 / 10 / 2011$ \\
\hline Rock wall & $4 / 16$ & 2215 & Northwest & Air-rock interface & $04 / 11 / 2007$ to $24 / 10 / 2011$ \\
\hline
\end{tabular}

geomorphological processes existing in the glacial cirque. In order to examine the thermal regime of the ground and near-rock surface air in the Forcadona area and determine its control on periglacial dynamics, between 2006 and 2011, we installed five dataloggers Hanna HI141BH (for ground temperatures) and $\mathrm{HI} 141 \mathrm{AH}$ (for near-rock surface air temperatures). These loggers show an accuracy of $\pm 0.4{ }^{\circ} \mathrm{C}$ and were set up at sites with distinct elevations, aspects and geomorphological settings (Table 1). One logger was installed $16 \mathrm{~m}$ above the cirque floor at a rock wall, while three were buried at $10 \mathrm{~cm}$ depth across the cirque floor and another at $50 \mathrm{~cm}$ depth (Fig. 2). The loggers collected data every $2 \mathrm{~h}$. The monitoring period for each site is summarized in Table 1. No data from the talus site are available after 7 August 2011.

From these data we calculated mean, maximum and minimum daily temperatures and temperature ranges. Annual parameters were calculated from November to October. Ground thermal dynamics was described according to parameters commonly used in periglacial studies (Vieira et al., 2003; Frauenfeld et al., 2007; French, 2007):

1) Cumulative sums of thawing and freezing degree days (1)

2) Total number of thawing days, defined as days with daily minimum $>0.1{ }^{\circ} \mathrm{C}$ and maximum $>0.5{ }^{\circ} \mathrm{C}$

3) Total number of freezing days, defined as with daily maximum $<-0.1{ }^{\circ} \mathrm{C}$ and minimum $<-0.5{ }^{\circ} \mathrm{C}$

4) Isothermal days including days with all daily values of ground temperatures $<-0.5{ }^{\circ} \mathrm{C}$ and $<0.5{ }^{\circ} \mathrm{C}$
5) Freeze-thawing days with at least one value $>0.5{ }^{\circ} \mathrm{C}$ and one value $<-0.5{ }^{\circ} \mathrm{C}$

6) Thermally undefined days, which were not included in any category

$T D D=\int_{0}^{\theta_{s}} T_{G z}-T_{F} d t \approx \sum_{0}^{\theta_{s}} \bar{T}_{S}$

where TDD represents sum of seasons thawing degree days, $T_{G Z}$ is ground temperature at depth $\mathrm{z}, \mathrm{T}_{\mathrm{F}}$ is $0{ }^{\circ} \mathrm{C}, \theta_{S}$ is duration of thawing season and $T_{S}$ is mean daily surface temperature. Freezing degree days are calculated according to equivalent equation (Riseborough, 2003).

The climate framework between 2006 and 2011 was generated examining air temperatures and precipitation provided by the Spanish Meteorological Agency (AEMET). The reference meteorological station is Buferrera station, at $1080 \mathrm{~m}$ a.s.l., and $8.5 \mathrm{~km}$ north of the study site $\left(43^{\circ} 16^{\prime} 38^{\prime \prime} \mathrm{N}-4^{\circ} 59^{\prime} 09^{\prime \prime} \mathrm{W}\right.$; Fig. 1). Daily air maximum and minimum temperatures and precipitation were used to calculate mean monthly temperatures and monthly sums of precipitation, respectively. Mean monthly temperatures were extrapolated for the Forcadona area (almost $1000 \mathrm{~m}$ higher) using the regional vertical temperature gradient of $-0.56{ }^{\circ} \mathrm{C} / 100 \mathrm{~m}$ (Muñoz, 1982). Based on photographs taken along the successive field campaigns between 2007 and 2011 at the end of

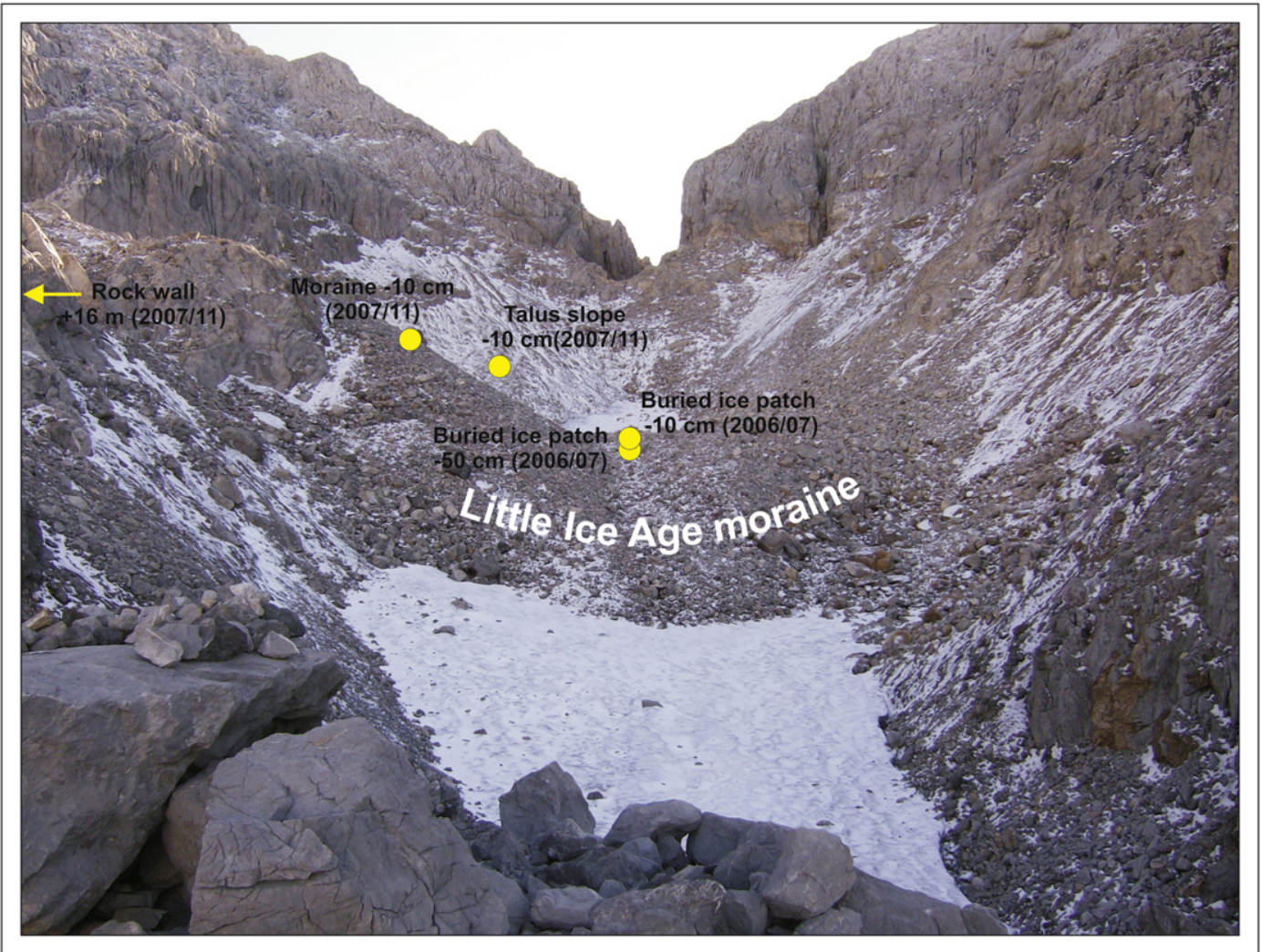

Fig. 2. General view of the study area with the location of the study sites. 

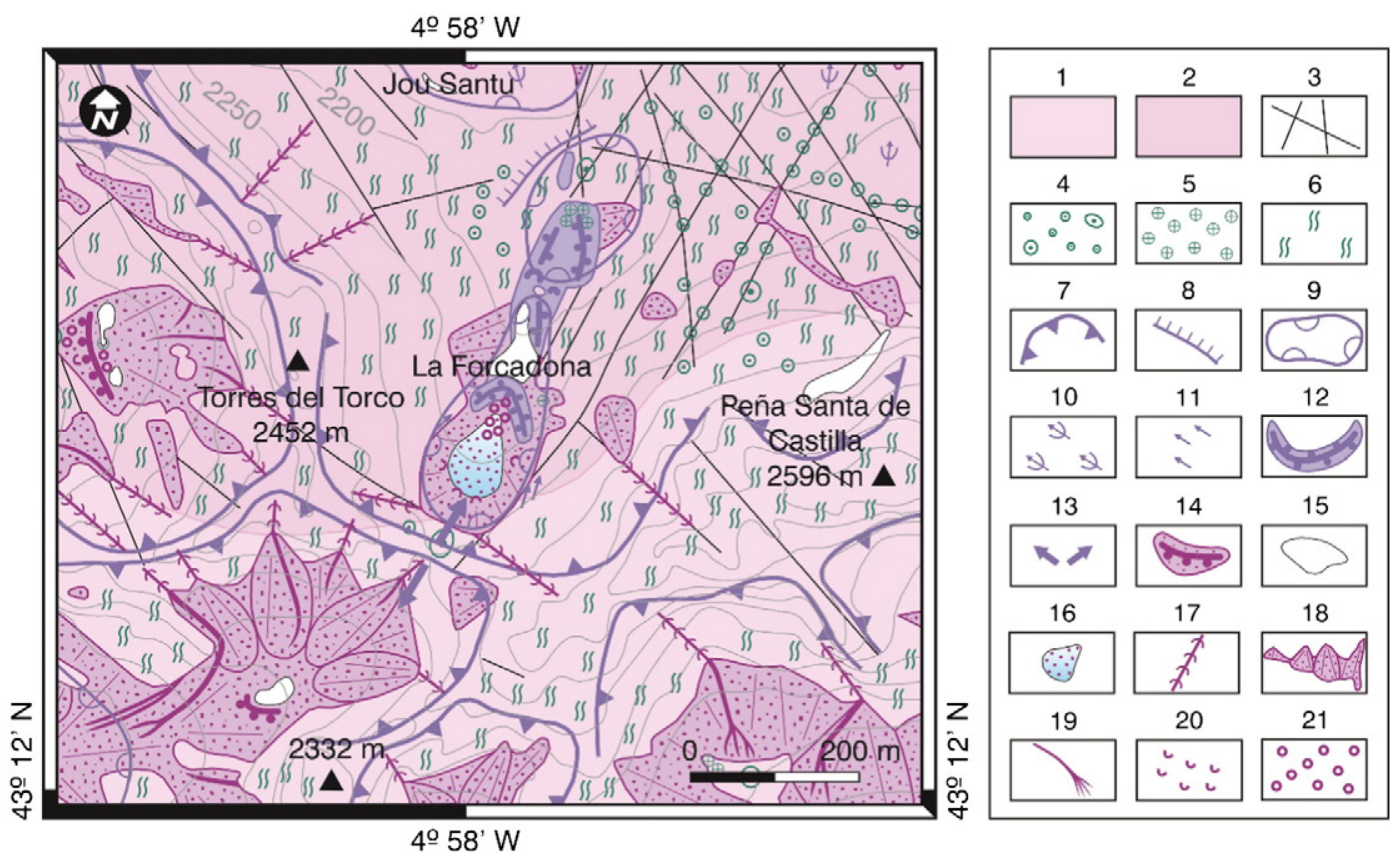

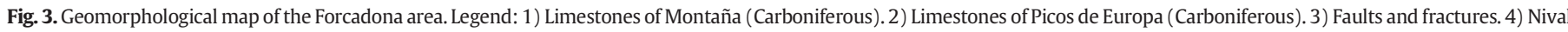

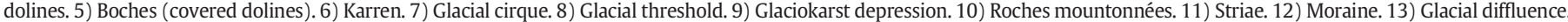
14) Pronival rampart. 15) Snow patch. 16) Buried ice patch. 17) Snow avalanche channel. 18) Talus slopes. 19) Debris flow. 20) Solifluction lobes. 21) Sorted stone circles.

the melting season (early to late October), we have mapped the snow cover duration in the Forcadona area.

\section{Results}

4.1. Distribution of geomorphological processes and landforms in the Forcadona area

The Forcadona buried ice patch is located in a glaciokarst depression covering an area of 3.5 ha. This depression is located inside a glacial cirque of 10.6 ha carved between the peaks Peña Santa de Castilla (east) and Torres del Torco (west) (Fig. 3). The area remained almost snow-free at the end of the summer of 2003, being described as a stratified ice body showing no movement (González-Trueba, 2005, 2006; González-Trueba et al., 2008). The frozen body is protected from direct solar radiation by a debris cover distributed across the bottom of the glaciokarst depression. The buried ice patch ends in a small frontal moraine at $2220 \mathrm{~m}, 7 \mathrm{~m}$ high and ci. $60 \mathrm{~m}$ long (Figs. 2 and 3). The moraine is completely devoid of vegetation. The scarce bedrock areas located within the moraine show fresh glacial striations.

The presence of decimetric active sorted stone circles on the debris distributed across the bottom of the glacial cirque shows evidence of the intensity of present-day cryoturbation processes (Fig. 4A). Periglacial landforms such as ephemeral frost mounds are also present (González-Trueba, 2007a). The talus slope connecting the wall of the glacial cirque with the bottom is affected by very intense slope dynamics. Intense frost shattering on the cirque walls generates abundant particles that are being remobilized downslope by snow avalanches and debris flows (Fig. 4B), rock falls and surface runoff. Solifluction generates stone-banked lobes at the foot of the talus slope.

4.2. Air temperature, precipitations and snow cover extent during the study period

The mean annual air temperature at Buferrera station from November 2006 to October 2011 was $9.4{ }^{\circ} \mathrm{C}$ (Fig. 5), which extrapolates to
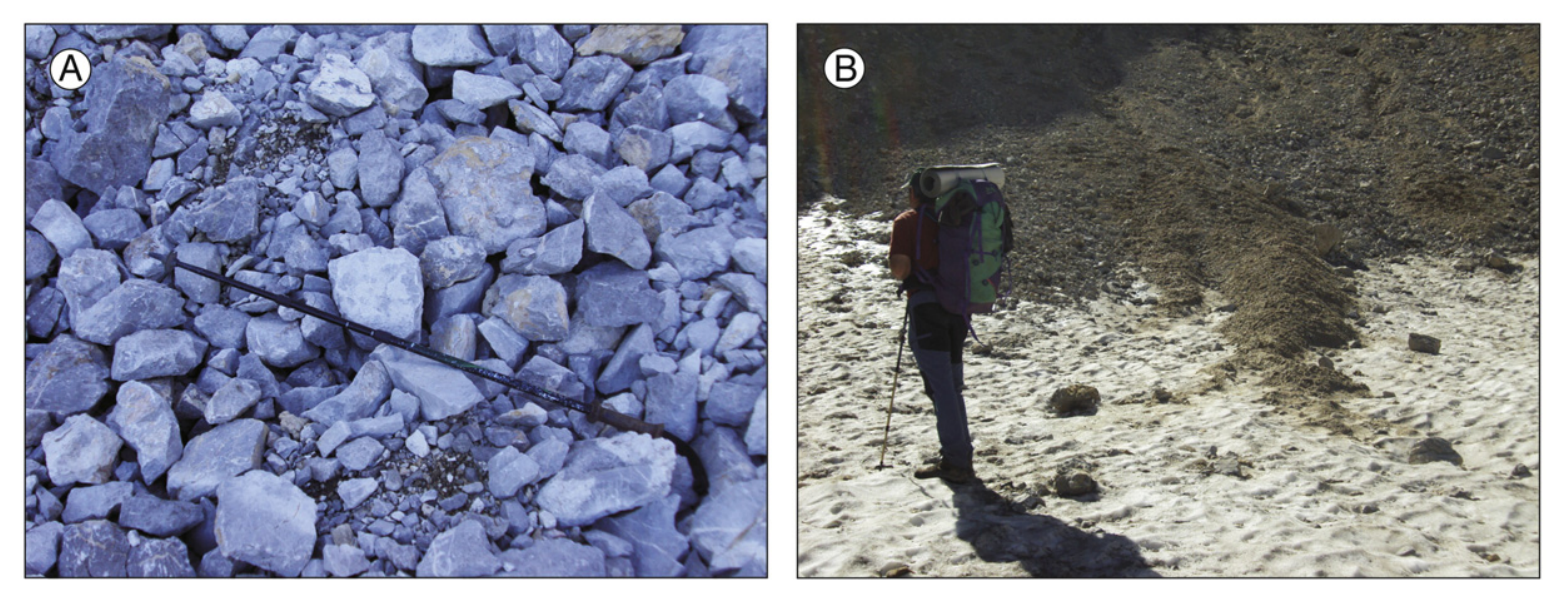

Fig. 4. Example of periglacial landforms in the Forcadona cirque: sorted stone circles (A), and debris flows generated after a storm event in September 2011 (B), 

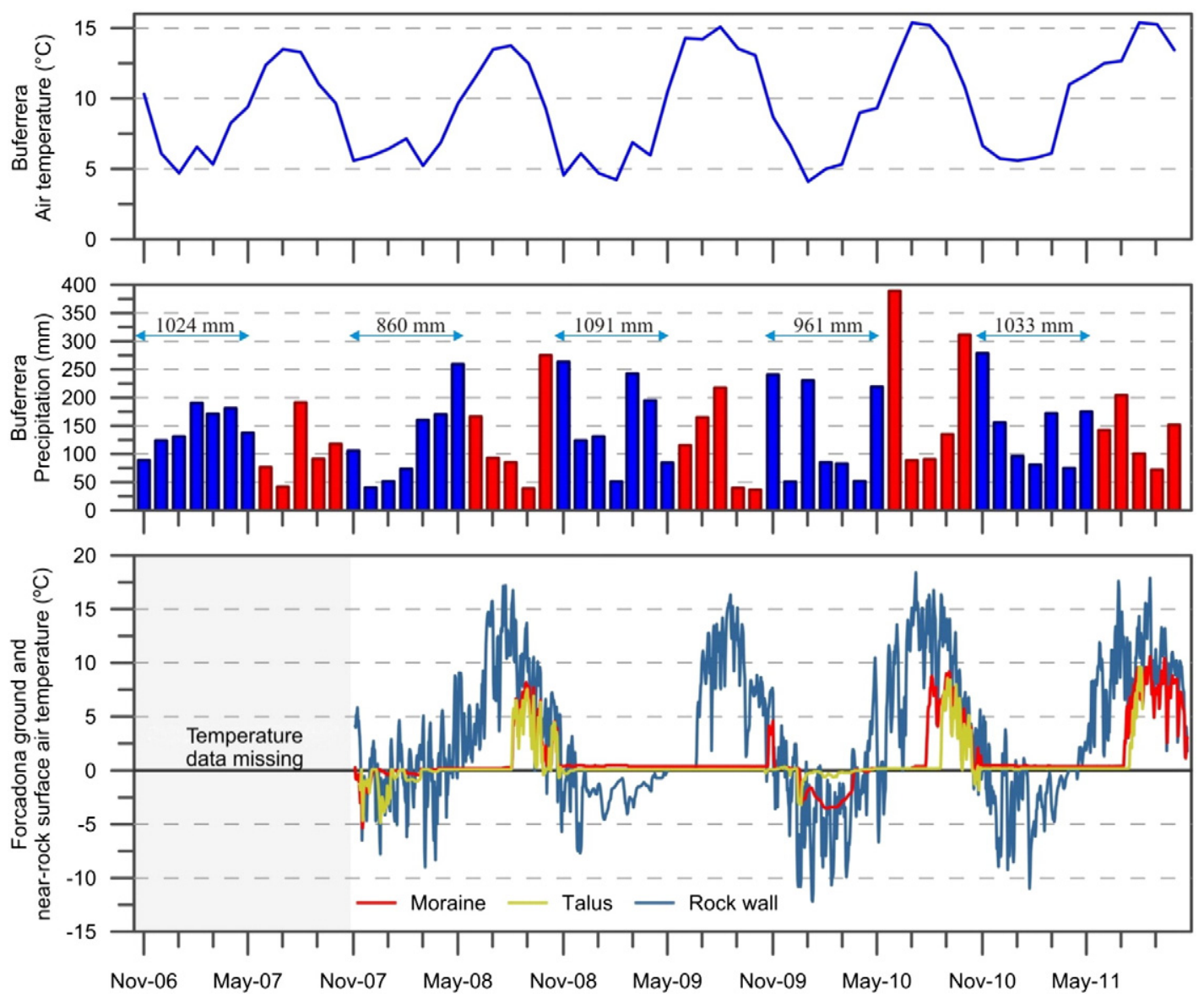

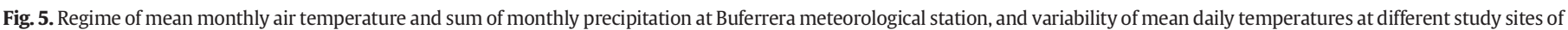
the Forcadona area (talus slope, moraine and rock wall) for the period November 2007 to October 2010.

$2.9^{\circ} \mathrm{C}$ at $2250 \mathrm{~m}$. The warmest months at Buferrera were June 2010 and August-September 2011 with mean monthly air temperatures of $15.3^{\circ} \mathrm{C}\left(8.8^{\circ} \mathrm{C}\right.$ at $\left.2250 \mathrm{~m}\right)$, while the lowest were observed in February 2009 and January 2010 with $4.2^{\circ} \mathrm{C}\left(-2.3^{\circ} \mathrm{C}\right.$ at $\left.2250 \mathrm{~m}\right)$. The mean annual precipitation at Buferrera over the whole period reached $1680 \mathrm{~mm}$, varying between $1518 \mathrm{~mm}$ (2007/08) and $1975 \mathrm{~mm}$ (2009/10). The seasonal regime of the precipitation showed the highest mean seasonal sums in spring ( $450 \mathrm{~mm}$ ) and the lowest in summer (137 mm) (Fig. 5).

The semi-permanent snow field distributed above the area where the buried ice patch is located showed significant interannual variations at the end of the melting season during the study period. In 2009 the snow field was by far the most extensive in comparison with the rest of the years (Fig. 6). This year was characterized by the highest precipitation between November 2008 and May 2009 of all years studied $(1091 \mathrm{~mm})$ at Buferrera. Other years with large snow cover in the Forcadona at the end of the melting season were 2008 and 2010 (Fig. 6 ). The year $2007 / 08$ was conditioned by the lowest precipitation values of the study years between November 2007 and May 2008 (860 mm), but recorded also cool temperatures between June and October $\left(12 .{ }^{\circ} \mathrm{C}\right)$. In $2009 / 10$ precipitation was below average between

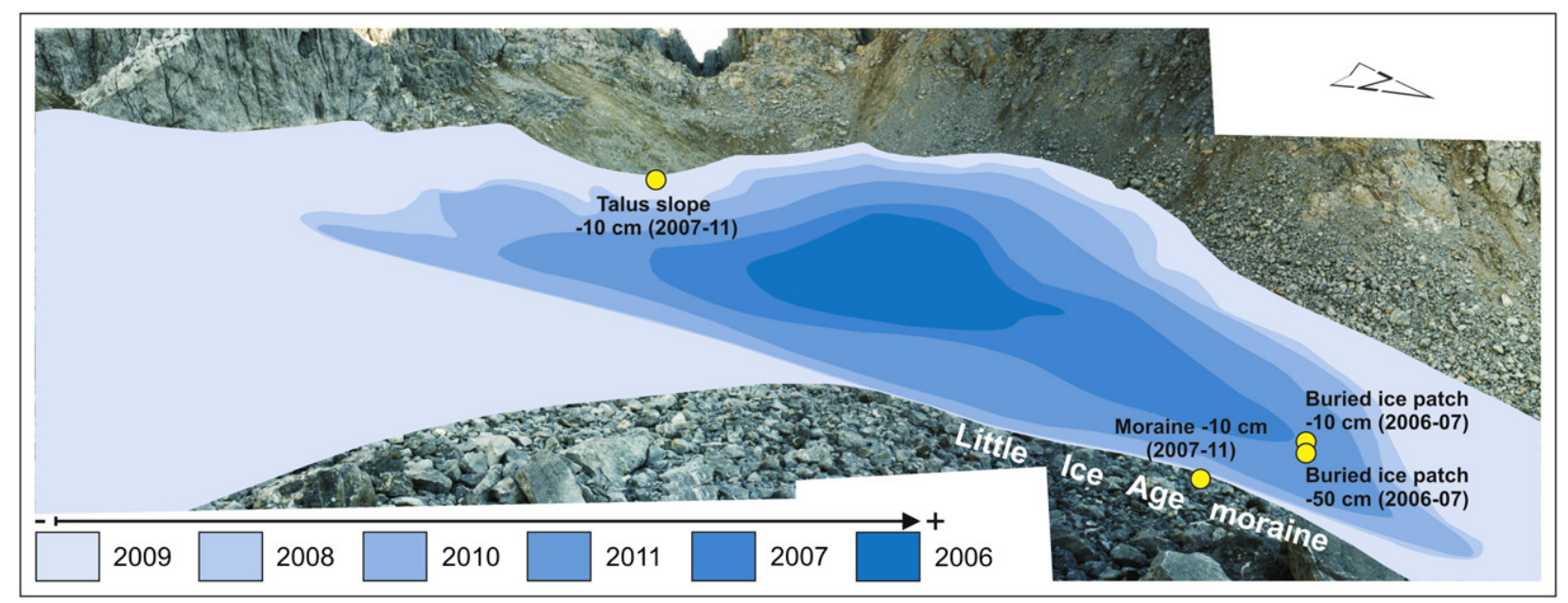

Fig. 6. Persistence of the surface area covered by snow at the end of the melting season at the Forcadona area between 2007 and 2011. 


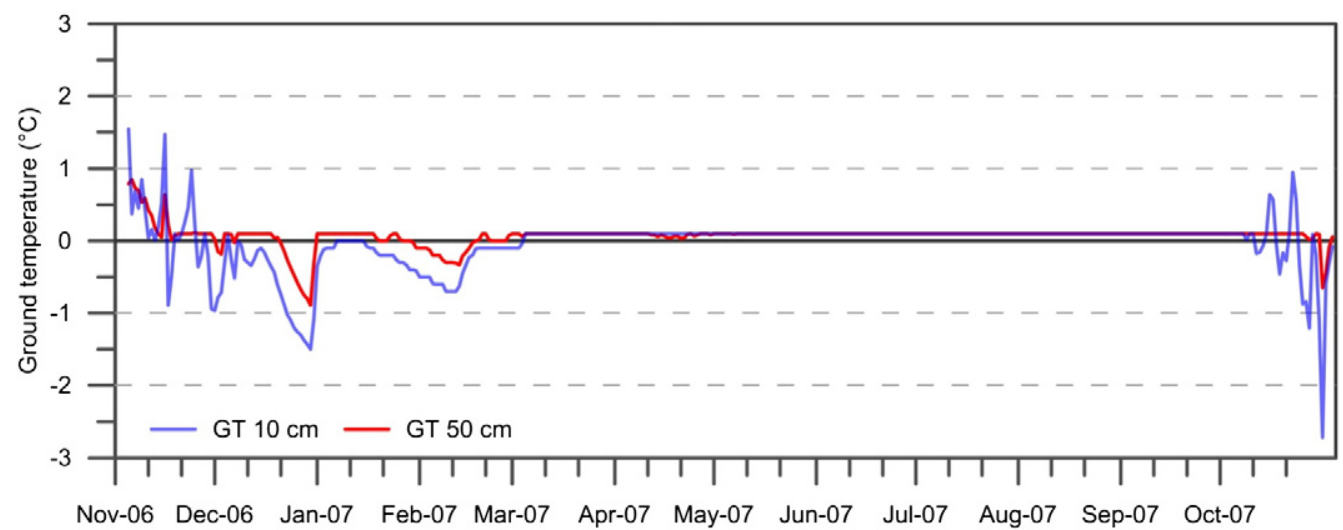

Fig. 7. Variability of mean daily ground temperatures between November 2006 and November 2007 at 10 and $50 \mathrm{~cm}$ at the buried ice patch experimental site.

November and May (961 mm) and summer temperatures were above average $\left(13.5^{\circ} \mathrm{C}\right)$.

The years in which the snow field occupied less surface area at the end of the melting season were 2006 and 2007 (Fig. 6). Snow accumulation during the cold months and summer temperatures may explain this fact. Between November 2005 and May 2006 precipitation was scarce $(940 \mathrm{~mm})$ and summer temperatures were the highest at the Buferrera meteorological station $\left(14.2^{\circ} \mathrm{C}\right)$ between June and October 2006. By contrast, the precipitation between November 2006 and May 2007 were higher (1024 mm), but the summer temperatures of 2007 were the lowest of the entire period $\left(11.9^{\circ} \mathrm{C}\right)$.

\subsection{Ground and near-surface air temperatures}

\subsubsection{Ground temperatures in the Forcadona ice patch between 2006 and 2007}

Ground temperatures in November were characterized by daily thermal oscillations around $0{ }^{\circ} \mathrm{C}$. From early December to early March 2007 temperatures were slightly negative, between 0 and $-1.5^{\circ} \mathrm{C}$. Between March and mid-October ground temperatures stabilized near $0{ }^{\circ} \mathrm{C}$ and daily oscillations were recorded again in mid-October.

The thermal regime at 10 and $50 \mathrm{~cm}$ depth showed a very stable dynamics in the buried ice patch experimental site from November 2006 to November 2007 (Fig. 7, Table 2). The mean annual ground temperature (MAGT) was $0.0{ }^{\circ} \mathrm{C}(10 \mathrm{~cm})$ and $0.1{ }^{\circ} \mathrm{C}(50 \mathrm{~cm})$. The maximum ground temperature ranged between $2.9{ }^{\circ} \mathrm{C}(10 \mathrm{~cm})$ and $1.2{ }^{\circ} \mathrm{C}$ $(50 \mathrm{~cm})$, while the minimum oscillated between $-3.3^{\circ} \mathrm{C}(10 \mathrm{~cm})$ and $-0.9^{\circ} \mathrm{C}(50 \mathrm{~cm})$. Consequently, there was a very low annual thermal amplitude ranging between $6.2{ }^{\circ} \mathrm{C}(10 \mathrm{~cm})$ and $2.1{ }^{\circ} \mathrm{C}(50 \mathrm{~cm})$. The total sum of thawing-degree days (TDD) fluctuated between $34{ }^{\circ} \mathrm{C}$ day $(10 \mathrm{~cm})$ and $35^{\circ} \mathrm{C}$ day $(50 \mathrm{~cm})$, while the total sums of freezingdegree days (FDD) were $-48{ }^{\circ} \mathrm{C}$ day $(10 \mathrm{~cm})$ and $-10{ }^{\circ} \mathrm{C}$ day $(50 \mathrm{~cm})$. Isothermal days were the most frequent regime, with 296 days at $10 \mathrm{~cm}$ and 347 days at $50 \mathrm{~cm}$. The occurrence of other types of thermally defined days was significantly lower (Table 2).

Table 2

Thermal characteristics of the buried ice patch site at 10 and $50 \mathrm{~cm}$ depth in period November 2006 to November 2007.

\begin{tabular}{lrrlrc}
\hline & $10 \mathrm{~cm}$ & \multicolumn{1}{c}{$50 \mathrm{~cm}$} & & $10 \mathrm{~cm}$ & $50 \mathrm{~cm}$ \\
\hline MAGT & 0.0 & 0.1 & Thawing days & 2 & 2 \\
Max & 2.9 & 1.2 & Freezing days & 23 & 4 \\
Min & -3.3 & -0.9 & Freeze-thawing days & 3 & 0 \\
TDD & 34 & 35 & Isothermal days & 296 & 347 \\
FDD & -48 & -10 & Unclassified days & 42 & 13
\end{tabular}

4.3.2. Evolution of ground and near-rock surface air temperatures near the Forcadona ice patch between 2007 and 2011

We have analysed the thermal characteristics (Table 3), the number of thermally defined days (Table 4 ) as well as the variability of ground temperatures at $10 \mathrm{~cm}$ depth at the talus and moraine sites and at the near-rock surface air in a cirque wall for the period 2007-2011 (Fig. 5).

4.3.2.1. Talus slope. The daily oscillations of ground temperatures started between mid July and early November and ended in late November. Negative temperatures were recorded between mid-October and late November. Since then until August or early November, ground temperatures stabilized near $0{ }^{\circ} \mathrm{C}$. However, there were also periods in which ground temperatures fluctuated below $0{ }^{\circ} \mathrm{C}$, as it occurred from November 2007 to March 2008 and between January and May 2010.

Thermal dynamics at this site showed also a rather stable regime (Table 3). The MAGT in $2007 / 11$ reached $0.6{ }^{\circ} \mathrm{C}$, varying between $0.0{ }^{\circ} \mathrm{C}(2008 / 09)$ and $0.6{ }^{\circ} \mathrm{C}(2009 / 10)$. The higher MAGT in 2010/11 $\left(1.3^{\circ} \mathrm{C}\right)$ was conditioned by the lack of data from 7 August to the end of the monitoring year. The maximum ground temperatures were observed in $2010 / 11\left(12.5^{\circ} \mathrm{C}\right)$ while the minimum $\left(-5.1{ }^{\circ} \mathrm{C}\right)$ were observed in $2007 / 08$. The total sum of TDD reached $670{ }^{\circ} \mathrm{C}$ day, varied between $0{ }^{\circ} \mathrm{C}$ day $(2008 / 09)$ and $274{ }^{\circ} \mathrm{C}$ day $(2008 / 08)$. The total sum of FDD reached $-169{ }^{\circ} \mathrm{C}$ day with the minimum of $-129{ }^{\circ} \mathrm{C}$ day in $2007 / 08$, while $0{ }^{\circ} \mathrm{C}$ day were detected on 2008/09 and 2010/11 (Table 3). Most of the thermally defined days during the entire period 2007/11 were classified as isothermal (1172 days) which were the

Table 3

Thermal characteristics of the different study sites (talus, moraine and rock wall) for the period November 2007 to October 2011.

\begin{tabular}{llrrrr}
\hline & MAGT & Max & \multicolumn{1}{l}{ Min } & TDD & \multicolumn{1}{c}{ FDD } \\
\hline Talus & & & & & -129 \\
$2007-08$ & 0.4 & 10.3 & -5.1 & 274 & -0 \\
$2008-09$ & 0.0 & 0.1 & -0.4 & 0 & -40 \\
$2009-10$ & 0.6 & 9.3 & -3.3 & 257 & 0 \\
$2010-11$ & 1.3 & 12.5 & 0.1 & 139 & -169 \\
$2007-11$ & 0.6 & 12.5 & -5.1 & 670 & \\
Moraine & & & & & -48 \\
$2007-08$ & 0.8 & 15.3 & -5.5 & 327 & 0 \\
$2008-09$ & 0.5 & 5.4 & 0.3 & 28 & -252 \\
$2009-10$ & 0.7 & 12.7 & -3.4 & 488 & -300 \\
$2010-11$ & 2.5 & 13.7 & 0.3 & 769 & \\
$2007-11$ & 1.1 & 15.3 & -5.5 & 1612 & -273 \\
Rock wall & & & & & -346 \\
$2007-08$ & 3.5 & 26.6 & -12 & 1567 & -603 \\
$2008-09$ & 2.4 & 21.6 & -8.5 & 1223 & -412 \\
$2009-10$ & 2.9 & 23.4 & -14.3 & 1661 & -1634 \\
$2010-11$ & 3.5 & 22.9 & -12.4 & 1648 & 6099 \\
$2007-11$ & 3.1 & 26.6 & -14.3 & & \\
\hline
\end{tabular}


Table 4

Annual occurrences of thermally defined days at the different study sites (talus, moraine and rock wall) for the period November 2007 to October 2011.

\begin{tabular}{lrrlrr}
\hline & Thawing & Freezing & Fr-thaw & Isothermal & Undefined \\
\hline Talus & & & & & \\
$2007-08$ & 63 & 75 & 0 & 201 & 27 \\
$2008-09$ & 0 & 0 & 0 & 365 & 0 \\
$2009-10$ & 51 & 36 & 0 & 271 & 7 \\
$2010-11$ & 24 & 0 & 0 & 335 & 6 \\
$2007-11$ & 138 & 111 & 0 & 1172 & 40 \\
Moraine & & & & & \\
$2007-08$ & 76 & 26 & 0 & 256 & 8 \\
$2008-09$ & 8 & 0 & 0 & 357 & 0 \\
$2009-10$ & 95 & 94 & 0 & 174 & 2 \\
$2010-11$ & 111 & 0 & 0 & 248 & 6 \\
$2007-11$ & 290 & 120 & 0 & 1035 & 16 \\
Rock wall & & & & & \\
$2007-08$ & 175 & 42 & 105 & 0 & 44 \\
$2008-09$ & 131 & 148 & 11 & 59 & 16 \\
$2009-10$ & 182 & 98 & 47 & 0 & 38 \\
$2010-11$ & 188 & 104 & 24 & 20 & 29 \\
$2007-11$ & 676 & 392 & 187 & 79 & 127 \\
\hline
\end{tabular}

only type of thermally defined days observed in 2008/09 (Fig. 8). The total number of thawing days (138 days) was higher than the freezing days (111). Freeze-thawing days were not observed at this site (Table 4, Fig. 8).

4.3.2.2. Moraine. Snow cover shows a shorter persistence at the moraine site with respect to the talus slope (Fig. 5): one month less in 2010 and ten days in 2011. The MAGT over the study period at the moraine was $1.1^{\circ} \mathrm{C}$. The warmest year was $2010-11\left(2.5^{\circ} \mathrm{C}\right)$, and the coldest in $2008 / 09\left(0.5^{\circ} \mathrm{C}\right)$. Both maximum $\left(15.3^{\circ} \mathrm{C}\right)$ and minimum $\left(-5.5^{\circ} \mathrm{C}\right)$ ground temperatures were recorded in $2007 / 08$. The total sum of TDD reached $1612{ }^{\circ} \mathrm{C}$ day during the entire study period with a maximum in $2010 / 11$ ( $769{ }^{\circ} \mathrm{C}$ day) and minimum in $2008 / 09$ ( $28^{\circ} \mathrm{C}$ day). The total sum of FDD was $-300{ }^{\circ} \mathrm{C}$ day with the lowest accumulation in $2009 / 10\left(-252{ }^{\circ} \mathrm{C}\right.$ day), while in 2008/09 and 2010/11 no FDD were observed (Table 3 ). The vast majority of the days were classified as isothermal, with a total occurrence of 1035 days over the period 2007/11, being maximum in 2008/09 (357 days) and minimum in 2009/10 (174 days). In contrast to the very high number of isothermal days, 290 days were classified as thawing and 120 days as freezing for the whole study period. Similarly as in the talus site, freeze-thawing days were not observed (Fig. 8). The total number of undefined days were 16 for the whole period (Table 4).

4.3.2.3. Near-rock surface air temperature. This site, located in a rock wall (NW aspect), showed a very distinct thermal regime than the moraine and talus sites (Table 3, Fig. 5). The thermal evolution was characterized by the repetitive thermal oscillation throughout the year. From June or July until mid-October or early November, temperatures oscillated always above $0{ }^{\circ} \mathrm{C}$. However, between early December and mid-March, temperatures were in general negative. Between the two periods two phases recorded a significant number of freeze-thaw cycles occurred (Fig. 5).

The MAGT was $3.1{ }^{\circ} \mathrm{C}$ for the period $2007 / 11$, with a maximum of $3.5^{\circ} \mathrm{C}$ in $2007 / 08$ and $2010 / 11$ and a minimum of $2.4{ }^{\circ} \mathrm{C}$ in $2008 / 09$. The annual maximum temperature exceeded $21.6{ }^{\circ} \mathrm{C}$ every year, reaching a maximum of $26.6^{\circ} \mathrm{C}$ in $2007 / 08$. The annual minimum temperatures varied between $-8.5{ }^{\circ} \mathrm{C}(2008 / 09)$ and $-14.3^{\circ} \mathrm{C}(2009 / 10)$. The total sum of TDD attained $6099^{\circ} \mathrm{C}$ day for the entire period, with annual values varying between $1223^{\circ} \mathrm{C}$ day $(2008 / 09)$ and $1661{ }^{\circ} \mathrm{C}$ day $(2009 / 10)$. The total sum of FDD reached $-1634^{\circ} \mathrm{C}$ day in $2007 / 11$. The minimum was observed in $2009 / 10\left(-603^{\circ} \mathrm{C}\right.$ day $)$ and the highest in $2007 / 08$ ( $-273^{\circ} \mathrm{C}$ day) (Table 4$)$. In a similar way, the occurrence of thermally defined days showed a completely different pattern than at the moraine and talus sites. The most repeated near-rock surface air regime between 2007 and 2011 was thawing days (676 days), oscillating between 131 days (2008/09) and 188 days (2010/11). The total number of freezing days was lower (392 days), being maximum in 2008/09 (148 days) and minimum in 2007/08 (42 days). Freeze-thawing days showed a very irregular occurrence, with a total of 187 days for the period 2007-11. In 2007/08 up to 105 freeze-thawing days were recorded, but only between 11 and 47 days in the following years (Fig. 8). Isothermal days were only observed in 2008/09 (59 days) and 2010/ 11 (20 days). Undefined thermal days were observed every year of the study period, reaching up to 127 days for the period 2007/11 (Table 4).

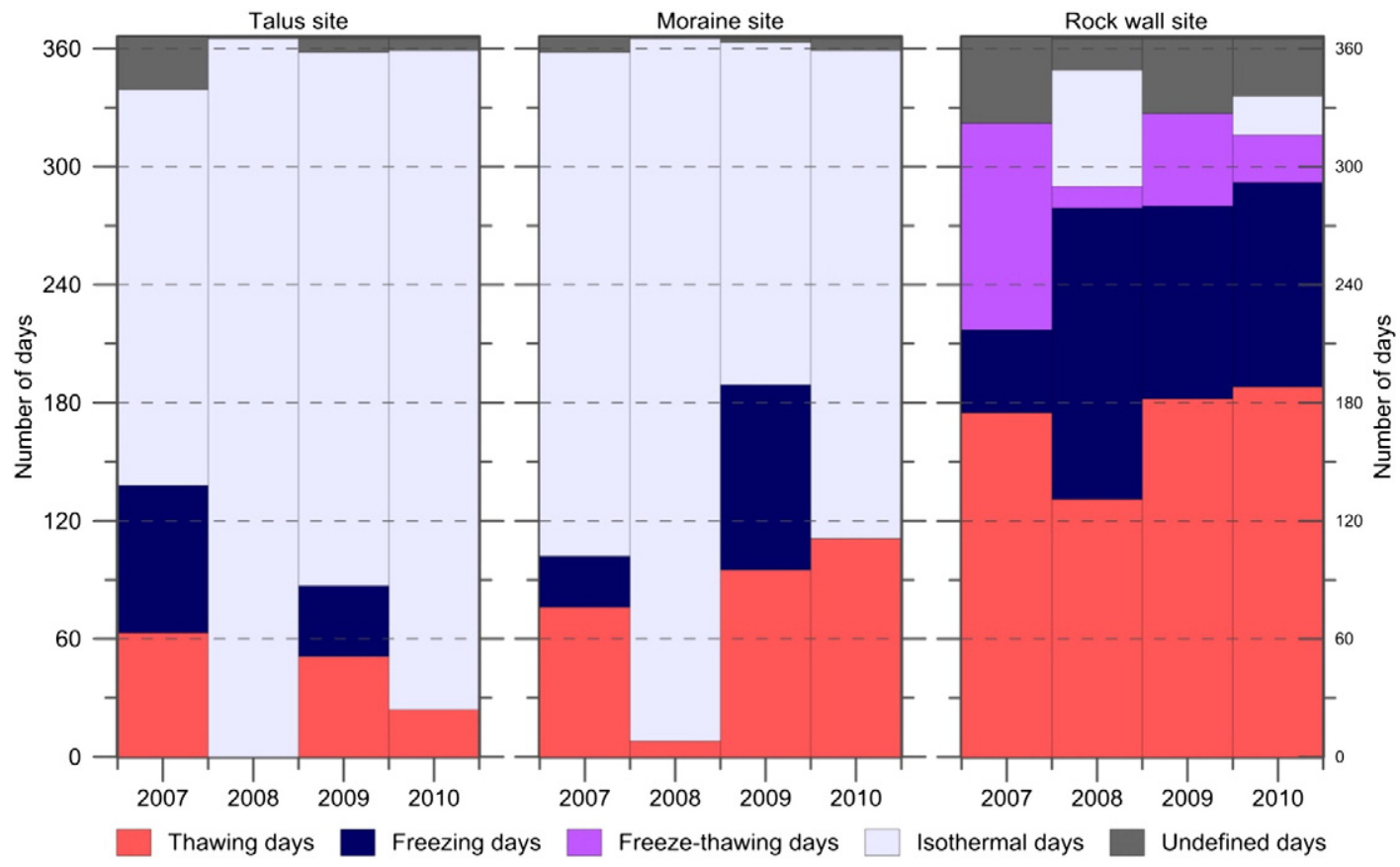

Fig. 8. Summary of thermally defined days at talus, moraine and rock wall sites for the period 2007-2011. 


\section{Discussion}

\subsection{Ground and near-surface air thermal regimes in the Forcadona area}

We monitored ground and near-surface air temperatures in three distinct geomorphological and topographical sites over the period 2007-11. No widespread permafrost conditions were detected in the Forcadona area. In the bottom of the glacial cirque, the presence of the snow field conditioned the lowest temperatures across the area, with MAGT of $0.1^{\circ} \mathrm{C}$ in $2006-2007$. Even if no data exist, it is likely to think about the existence of permanent negative temperatures at deeper layers in a similar sedimentary and thermal model to that already described in similar geomorphological environments such as the Veleta cirque, in Sierra Nevada: a layer of frozen debris composed of multisized blocks (permafrost) sitting in contact with a crystalline ice mass of glacial origin (Gómez-Ortiz et al., 2014).

Very different ground and near-rock surface air thermal regimes have been detected in the Forcadona area. Ground temperatures showed two distinct seasonal periods: 1) continuous thaw with daily thermal oscillations, from mid-summer to mid-autumn, and 2) isothermal regime near $0{ }^{\circ} \mathrm{C}$ from mid-autumn to mid-summer, highly controlled by the presence of snow cover. During the last period some temperature fluctuations below $0{ }^{\circ} \mathrm{C}$ were detected, due to instabilities of the snow cover. This pattern is repeatedly observed in the Cantabrian Mountains, where the clearance of snow in mid winter leads to a cooling of the ground (González-Trueba and Serrano, 2010; Pellitero, 2012). Two short transition periods were detected in between the two long phases. In the transition between the continuous thaw period and the isothermal period, temperature oscillations occurred above and below $0{ }^{\circ} \mathrm{C}$, strongly influenced by the irregularity and instability of the snow cover during the mid-autumn. However, near-rock surface air temperatures showed a very different annual thermal regime characterized by daily oscillation of temperatures with the following phases: 1) a continuous thaw period from early summer to mid-autumn, 2) a period with negative temperatures during the winter, and 3) two periods of freezethaw conditions between the two seasons.

Very similar and relatively stable soil thermal regimes were observed at the moraine and talus sites, while a significantly more dynamic regime was detected at the rock wall site (Fig. 9). MAGT over the period 2007-11 varied between $0.6{ }^{\circ} \mathrm{C}$ and $1.1{ }^{\circ} \mathrm{C}$ at the talus and moraine sites, respectively, but reached $3.1{ }^{\circ} \mathrm{C}$ at the rock wall site. Similarly, both annual maximum and minimum temperatures were more extreme on the exposed rock wall site, where maximum temperature varied between 21.6 and $26.6{ }^{\circ} \mathrm{C}$ compared to the moraine $\left(5.4{ }^{\circ} \mathrm{C}\right.$ to $\left.15.3^{\circ} \mathrm{C}\right)$ and talus sites $\left(0.1\right.$ to $\left.12.5^{\circ} \mathrm{C}\right)$. On the other hand, the minimum temperature at the rock wall site decreased from -8.5 to $-14.3^{\circ} \mathrm{C}$ while significantly higher temperatures were observed at the moraine
( -5.5 to $0.3^{\circ} \mathrm{C}$ ) and talus sites $\left(-5.1\right.$ to $0.1{ }^{\circ} \mathrm{C}$ ). Finally, the most pronounced differences between the study sites were observed when comparing the sums of TDD and FDD for the study period 2007-11. The highest sum of TDD $\left(6099{ }^{\circ} \mathrm{C}\right.$ days) was observed at the rock wall, which was almost four times higher TDD than at the moraine $\left(1612{ }^{\circ} \mathrm{C}\right.$ day) and even more than nine times higher TDD than at the talus $\left(670{ }^{\circ} \mathrm{C}\right.$ day). Similarly, the lowest sum of FDD $\left(-1634{ }^{\circ} \mathrm{C}\right.$ day $)$ was observed at the rock wall, while the total sums of FDD were more than five times lower at the moraine $\left(-300{ }^{\circ} \mathrm{C}\right.$ day $)$ and more than nine times lower at the talus $\left(-169{ }^{\circ} \mathrm{C}\right.$ day $)$. Moreover, $0{ }^{\circ} \mathrm{C}$ day of FDD was observed at both the moraine and talus sites in 2008/09 and 2010/11. Very low or zero sums of FDD at the moraine and talus sites were recorded during the wet cold semester in 2008/09 (1091 mm) and $2010 / 11(1033 \mathrm{~mm})$ in comparison with the drier seasons in 2007/08 (860 mm) and 2009/10 (961 mm) (Fig. 5).

This relatively stable soil thermal dynamics at the moraine and talus sites with regard to freezing periods suggests the very important role of snow cover as very effective insulator of ground surface (Haeberli, 1973; Haeberli and Patzelt, 1982; Ishikawa, 2003; Frauenfeld et al., 2007). In general, snow cover thicker than ca. $40 \mathrm{~cm}$ leads to isothermal regime of ground temperature (Zhang, 2005). The total number of isothermal days varied between 1035 (moraine) and 1172 (talus) represents between 70 and $80 \%$ of all the days during the study period. This is related to a long persistence of snow in the area. By contrast, only 79 isothermal days (5\%) were observed at the rock wall site, which must be interpret as the low presence of snow at this site.

The surface occupied by the snow field distributed above the buried ice patch and the talus slope connecting with the cirque wall recorded significant variations at the end of the melting season during the period of 2006 to 2011. With the exception of 2010, the surface of the snow field was larger during the years with higher precipitation during the snowy season in the Forcadona area (November-May) and with lower temperatures during the warmer season (June-October). The large area occupied by the snow field at the end of the melting season of 2009 determined a significant extent in 2010, even if precipitation during the cold semester was scarce and summer temperatures were high. On the other hand, the lower extent of the snow field in 2006 is due to the scarce precipitation during the cold months and the high temperatures during the warm season.

\subsection{Relationship between landforms and thermal regimes}

Topography exerts a crucial role in controlling snow cover and duration, and thus soil temperatures in alpine environments (Gubler et al., 2011; Apaloo et al., 2012). At a microtopographical scale, the variability of the depth and persistence determines the degradation of orographically conditioned permafrost patches (Gadek and Leszkiewicz, 2012).

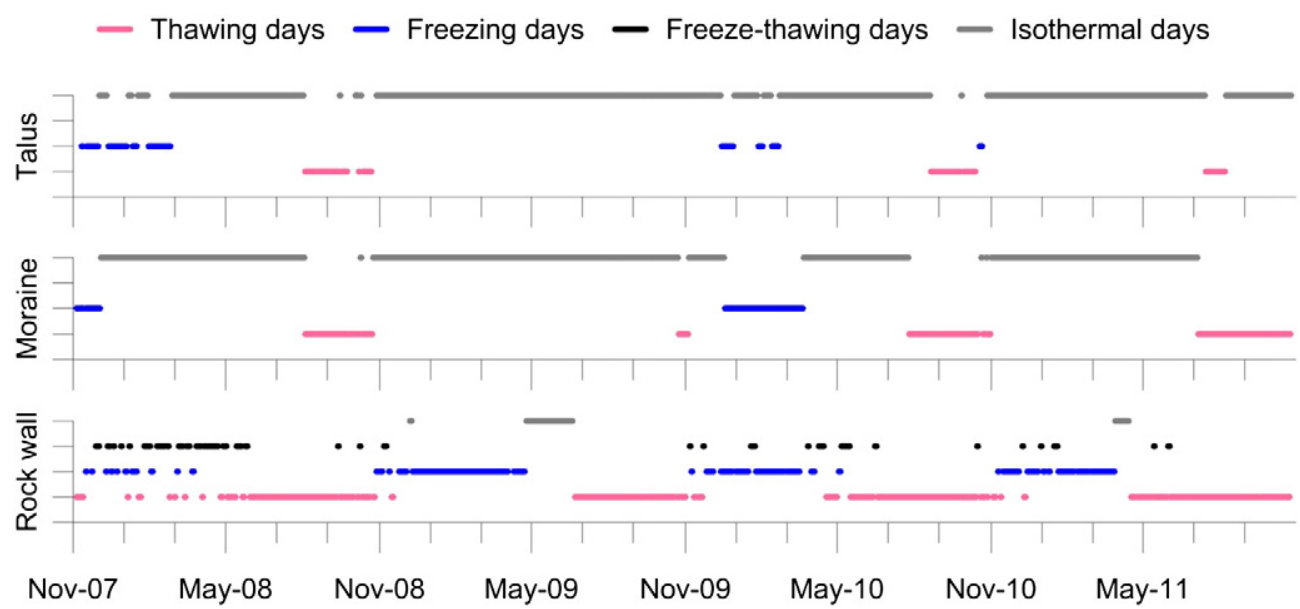

Fig. 9. Calendar of the thawing, freezing, freezing-thawing and isothermal days. 
The observations carried out between 2006 and 2011 in the Forcadona area, one of the few sites in the Cantabrian Mountain which held a glacier during the LIA (González-Trueba, 2005, 2006; González-Trueba et al., 2008), has shown evidence that seasonal frost conditions are widespread today in the high lands of the massif. The presence of ground ice during several months per year together with high moisture conditions explains the intensity of periglacial processes in the Forcadona area and other high lands of the Picos de Europa (Castañón and Frochoso, 1998; Serrano and González-Trueba, 2004; González-Trueba, 2007a; Ruiz-Fernández et al., 2014).

Even in those areas still concentrating ice patches such as the Forcadona area, MAGTs were positive during all the years in all the study sites; although in some cases MAGTs are very close to $0{ }^{\circ} \mathrm{C}$ (Serrano et al., 2011; Ruiz-Fernández et al., 2014). The Forcadona area receives abundant snow accumulation thanks to its location in a deep cirque receiving the snow swept away by the wind from the surrounding peaks and also by the triggering of snow avalanches. During the LIA when temperatures in Iberian mountains were between 0.8 and $1{ }^{\circ} \mathrm{C}$ (Chueca et al., 1998; González-Trueba et al., 2008; Oliva and Gómez Ortiz, 2012; Serrano et al., 2012, 2013), snow accumulated and turned to ice. The fact that the rock surfaces show clear glacial striations is indicative of its recent glacial origin, since nival karst processes have not eroded these microfeatures. Therefore, the Forcadona glacial cirque was occupied by a small glacier during a stage of very recent glacial advance. According to González-Trueba (2005, 2006), González-Trueba et al. (2008), and Serrano et al. (2012, 2013), the largest volume and maximum extension of the LIA glaciers of the Picos de Europa occur between the first third and the middle of the nineteenth century.

The talus site lies within the glacierized area during the LIA. This site is one of the areas in the cirque where the snow cover lasts longer and this is translated in the soil thermal regime. The fact that MAGT temperatures were $0.5^{\circ} \mathrm{C}$ lower than in the moraine site and FDD and TDD were also significantly lower shows evidence of the prominent role of snow cover in this area: the longer persistence of the snow at this site contributes to keep ground temperatures lower.

Finally, the logger installed between 2006 and 2007 which recorded a MAGT of $0.1{ }^{\circ} \mathrm{C}$ is located in the central area where the glacier exists during the LIA. The area is covered now by debris generated by frost shattering from the surrounding head walls, which may have buried the last remnants of glacial ice under the rocks (González-Trueba, 2005, 2006; González-Trueba et al., 2008; Serrano et al., 2011; Gómez-Ortiz et al., 2014; Ruiz-Fernández et al., 2014). At $0.5 \mathrm{~m}$ slightly positive temperatures were recorded during one year, which may be interpreted as close to the uppermost level of a frozen body.

\subsection{Ground thermal regime in Picos de Europa in comparison with other Iberian mountain areas}

The ground thermal regime in the Forcadona confirmed the thick and long-lasting snow cover in the area. Loggers installed at $10 \mathrm{~cm}$ depth showed evidence of the existence of snow cover in the area between 8 and 12 months annually. As in other mid-latitude mountain regions and polar environments, the thick snow cover in the high lands of Picos de Europa insulates thermally the ground from the external temperature oscillations (e.g. Brown, 1973; Goodrich, 1982; Zhang, 2005; Frauenfeld et al., 2007).

The first snowfall in Iberian mountain environments is highly dependent on the annual climate conditions, oscillating between late September and late October. During the study period, the first snow in the Forcadona took place between late September and late October or early November. The calendar of the first snow fall as well as the climate conditions prevailing during the next weeks were crucial to stabilize soil temperatures at around $0{ }^{\circ} \mathrm{C}$ (Veit and Höfner, 1993; Luetschg et al., 2008), which also stabilizes periglacial slope processes (Oliva et al., 2009). In the case of the Picos de Europa, periglacial dynamics is especially intense in the area when snow melts, because different processes are triggered, such as solifluction, debris flows, snow avalanches and runoff (Castañón and Frochoso, 1994, 1998; Serrano and González-Trueba, 2004; González-Trueba, 2007a; González-Trueba and Serrano, 2010; Ruiz-Fernández et al., 2014). The snowmelt water favours significantly the development of the nival karst in the areas of high altitude of the Picos de Europa (Miotke, 1968; Castañón and Frochoso, 1998; Serrano and González-Trueba, 2004; Santos and Marquínez, 2005; González-Trueba and Serrano, 2010; Ruiz-Fernández and Serrano, 2011; Ruiz-Fernández, 2015).

The annual thermal regime of the soil in the Forcadona area is defined by two main seasonal periods (continuous thaw with daily oscillations and isothermal regime), as well as two short transition periods. This timing is similar to that described previously in the Central Massif of the Picos de Europa by González-Trueba and Serrano (2010) and Pisabarro et al. (2015). In the Fuentes Carrionas Massif, Pellitero (2012) also has established an annual ground thermal regime analogous to that detected in the Forcadona.

MAGTs in the Forcadona area are also similar to those recorded in the Central Massif of the Picos de Europa, where there have registered annual average temperatures always above $0{ }^{\circ} \mathrm{C}$ (Pisabarro et al., 2015). The FDD of the soil in this massif also are similar to the data obtained in the Forcadona area (Pisabarro et al., 2015). In other Cantabrian Mountains such as Fornela, Gristredo, Mampodre and Peña Prieta, FDD have similar records (Santos-González et al., 2009). These authors further suggest the importance variability of the FDD depending mainly of the snow cover.

MAGTs in the Forcadona are comparable to those measured in similar studies in other high altitude environments in Iberia. In Sierra Neva$\mathrm{da}$, remnants of a LIA glacier are buried under rocks in the form of ice and permafrost inside the Veleta cirque (Gómez-Ortiz et al., 2001). This geomorphological setting is similar to that observed in the Forcadona area, where clear traces of crystalline ice were observed here in 2003 (González-Trueba, 2007b). Temperatures between 2000 and 2012 in the Veleta cirque reported $-1.1{ }^{\circ} \mathrm{C}$ at $1.5 \mathrm{~m}$ depth (Gómez-Ortiz et al., 2014) while $0.1{ }^{\circ} \mathrm{C}$ was measured at $0.5 \mathrm{~m}$ at the Forcadona area between 2006 and 2007. Therefore, in deeper levels temperatures may also reach permanent negative values along the year.

Ground temperatures at $10 \mathrm{~cm}$ show lower temperatures than in other high mountain areas in Iberia. Between 2006 and 2012 MAGT in a solifluction lobe (3005 $\mathrm{m}$ ) ranged from 2.3 and $4.8^{\circ} \mathrm{C}$ with an average of $3.7^{\circ} \mathrm{C}$ (Oliva et al., 2014b), whereas a MAGT in a sorted stone circle at $3297 \mathrm{~m}$ oscillated between 1.2 and 2.5 with an average of $1.8{ }^{\circ} \mathrm{C}$ (Salvador-Franch et al., 2011). In the Eastern Pyrenees, MAGTs at the same depth between 2007 and 2013 were $2.4,5.9$ and $6.3^{\circ} \mathrm{C}$ at 2730 , 2230 and $2160 \mathrm{~m}$ (Salvador-Franch et al., 2015). In the case of the Forcadona the talus and moraine sites showed significantly lower temperatures of 0.6 and $1.1^{\circ} \mathrm{C}$ (Table 3). Despite being located several hundreds of metres higher in southern and north-eastern Iberia, the MAGT difference must also be framed with the longer persistence of the snow in the Forcadona area (ca. 2 months) with respect to the other mountain environments.

The number of freeze-thaw days also varied significantly in the Forcadona area, oscillating between 0 in the moraine and talus slope and 105 in the rock wall (Table 4). This high interannual variability largely controlled by the presence or absence of snow cover has been also observed in other Iberian areas. In the Guadarrama massif, at $2212 \mathrm{~m}$, the number of freeze-thaw days ranged between 2 and 41 between 2002 and 2007 at $10 \mathrm{~cm}$ depth (Andrés and Palacios, 2010), while in Sierra Nevada it fluctuated annually between 0 and 10 at the same depth at $3005 \mathrm{~m}$ (Oliva et al., 2014b).

\section{Conclusions}

The Forcadona buried ice patch occupies a 3.5 ha glaciokarst depression located in a cirque glaciated during the LIA in the Western Massif of the Picos de Europa. In this paper we have presented a detailed 
geomorphological study of the Forcadona area and examined the thermal regime of the ground and near-rock surface air between 2006 and 2011.

The Forcadona area receives abundant snow accumulation that can be preserved thanks to its location in a cirque with very favourable topoclimatic conditions. During the study period, the first snow in the Forcadona took place between late September and late October or early November, contributing to stabilize soil temperatures at around $0{ }^{\circ} \mathrm{C}$ and generate geomorphic stability. As in other Cantabrian Mountains, the annual thermal regime of the soil is defined by two main seasonal periods; continuous thaw with daily oscillations and isothermal regime (with some ground temperature fluctuations due to instabilities of the snow cover), as well as two short transition periods.

Relatively stable thermal regimes were observed at the moraine and talus sites compared to those observed at the rock wall site, where temperatures were more extreme and a higher sum of TDD and lowest of FDD was observed. On the other hand, the talus site shows the highest sum of FDD days and the lowest of TDD. This relatively stable soil freezing dynamics, especially in the talus site, suggest that the thick and long-lasting snow cover in the area insulates thermally the ground from external temperature oscillations. This fact results in a high percentage of isothermal days at the moraine and talus sites (70-80\%), in comparison with that observed at the rock wall site (5\%). MAGTs and FDD are similar to those recorded in the Central Massif of the Picos de Europa, and in other Cantabrian Mountains. In the case of the talus and moraine sites showed significantly lower temperatures at $10 \mathrm{~cm}$, something that might be related with the longer persistence of the snow in this area (ca. 2 months) with respect to other Iberian mountains. Just like in other high altitude environments of the Peninsula, a high interannual variability in the number of freeze-thaw days has been observed, which is indicative of the prominent role of snow cover in insulating the ground surface.

The temperatures measured at $0.5 \mathrm{~m}$ depth at the Forcadona area during 2006-07 $\left(0.1^{\circ} \mathrm{C}\right)$ suggest that permanent negative values may be reached at deeper layers. Future studies will be conducted in the Forcadona buried ice patch area in order to monitor deeper soil and unveil the existence or absence of permafrost in the area.

\section{Acknowledgements}

The authors acknowledge the support provided by the Picos de Europa National Park during the fieldwork campaigns carried out between 2006 and 2011. Cristina García-Hernández gratefully thanks the Ministerio de Educación Cultura y Deporte fellowship programme FPU. The work of Filip Hrbáček was supported by the Masaryk University project MUNI/A/1315/2015 Integrated research of environmental changes in the landscape sphere.

\section{References}

Andrés, N., Palacios, D., 2010. Cobertura nival y distribución de la temperatura en el suelo en las cumbres de la Sierra de Guadarrama. España. Cuad. Investig. Geogr. 36 (2), 7-38.

Apaloo, J., Brenning, A., Bodin, X., 2012. Interactions between seasonal snow cover, ground surface temperature and topography (Andes of Santiago, Chile, $33.5 \mathrm{~S}$ ). Permafr. Periglac. Process. 23 (4), 277-291.

Ballesteros, D., Jiménez-Sánchez, M., Giralt, S., García-Sansegundo, J., Meléndez, M., 2015. A multi-method approach for speleogenetic research on alpine karst caves. Torca La Texa shaft, Picos de Europa (Spain). Geomorphology 247, 35-54.

Brosche, K.U., 1978. Formas actuales y límites inferiores periglaciares en la Península Ibérica. Estud. Geogr. 151, 131-161.

Brown, R.J., 1973. Influence of climate and terrain factors on ground temperatures at three locations in the permafrost region of Canada. Permafrost: North American Contribution, Second International Permafrost Conference, Yakutsk, URSS. National Academy of Science, Washington, pp. 27-34.

Carrera, P., Valcárcel, M., 2010. La acción geomorfológica del manto nivoso estacional en la Sierra de Ancares: vertiente nororiental del Pico Cuiña (León). Cuad. Investig. Geogr. 36, 85-98.

Castañón, J.C., Frochoso, M., 1994. El periglaciarismo de la Cordillera Cantábrica. In: Gómez-Ortiz, A., Simón, M., Salvador, F. (Eds.), Periglaciarismo en la Península Ibérica, Canarias y BalearesMonografías de la Sociedad Española de Geomorfología vol. 7. Servicio de Publicaciones de la Universidad de Granada, Granada, pp. 75-91.
Castañón, J.C., Frochoso, M., 1998. La alta Montaña Cantábrica: condiciones térmicas y morfodinámicas en los Picos de Europa. In: Gómez-Ortiz, A., Salvador, F., Schulte, L. García, A. (Eds.), Procesos biofísicos actuales en medios fríos. Universidad de Barcelona, Barcelona, pp. 113-132.

Chueca, J., Peña Monné, J.L., Lampre, F., Julián, A., 1998. La Pequeña Edad de Hielo en el Pirineo central y meridional. Inferencias paleoambientales a partir de datos geomorfológicos. In: Gómez Ortiz, A., Pérez Alberti, A. (Eds.), Las huellas glaciares de las montañas españolas. Servicio de Publicaciones de la Universidad de Santiago de Compostela, Santiago de Compostela, pp. 307-328.

Edwards, A.C., Scalenghe, R., Freppaz, M., 2007. Changes in the seasonal snow cover of alpine regions and its effect on soil processes: a review. Quat. Int. 162-163, 172-181.

Frauenfeld, O.W., Zhang, T., McCreight, J.L., 2007. Northern hemisphere freezing/thawing index variations over the twentieth century. Int. J. Climatol. 27, 47-63.

French, H.M., 2007. The Periglacial Environment. third ed. Wiley, Chichester, UK.

Frochoso, M., Castañón, J.C. 1998. El relieve glaciar de la Cordillera Cantábrica. In: GómezOrtiz, A., Pérez Alberti, A. (Eds.), Las huellas glaciares de las montañas españolas Servicio de publicaciones de la Universidad de Santiago de Compostela, Santiago de Compostela, pp. 65-137.

Gadek, B., Leszkiewicz, J., 2012. Impact of climate warming on the ground surface temperature in the sporadic permafrost zone of the Tatra Mountains, Poland and Slovakia. Cold Reg. Sci. Technol. 79-80, 75-83.

Gómez-Ortiz, A., Palacios, D., Ramos, M., Tanarro, L.M., Schulte, L, Salvador-Franch, F. 2001. Location of Permafrost in Marginal Regions: Corral del Veleta, Sierra Nevada (Spain). Permafr. Periglac. Process. 12, 93-110.

Gómez-Ortiz, A., Oliva, M., Salvador-Franch, F., Salvà-Catarineu, M., Palacios, D., Sanjosé, J.J., Tanarro, L., Galindo-Zaldívar, J., Sanz de Galdeano, C., 2014. Degradation of buried ice and permafrost in the Veleta cirque (Sierra Nevada, Spain) from 2006-2013. Solid Earth 5, 979-993.

González García, M., Serrano Cañadas, E., Sanjosé Blasco, J.J., González Trueba, J.J., 2016. Surface Dynamic of a Protalus Lobe in the Temperate High Mountain, Western Maladeta. Pyrenees, Catena http://dx.doi.org/10.1016/j.catena.2016.08.011.

González-Gutiérrez, R.B., 2002. El relieve de los valles del Torío y Curueño (Montaña Cantábrica Leonesa). Secretariado de Publicaciones de la Universidad de León, León.

González-Trueba, J.J., 2005. La Pequeña Edad del Hielo en los Picos de Europa (Cordillera Cantábrica, NO de España). Análisis morfológico y reconstrucción del avance glaciar histórico. Rev. C\&G 19 (3-4) pp. 79-94.

González-Trueba, J.J., 2006. Topoclimatical factors and very small glaciers in Atlantic mountain of SW Europe: Little Ice Age glacial advance in Picos de Europa (NW Spain). Z. Gletscherk. Glazialgeol. 39, 115-125.

González-Trueba, J.J., 2007a. Geomorfología del Macizo Central del Parque Nacional Picos de Europa. OAPN, Ministerio de Medio Ambiente, Madrid.

González-Trueba, J.J., 2007b. La Pequeña Edad del Hielo en los Picos de Europa. Fundación Marcelino Botín, Santander.

González-Trueba, J.J., Serrano, E., 2010. La nieve en los Picos de Europa. Cuad. Investig. Geogr. 36 (2), 61-84.

González-Trueba, J.J., Martín-Moreno, R., Martínez de Pisón, E., Serrano, E., 2008. Little Ice Age glaciation and current glaciers in the Iberian Peninsula. The Holocene 18 (4), 551-568.

Goodrich, L.E., 1982. The influence of snow cover on the ground thermal regime. Can. Geotech. J. 19, 421-432.

Gubler, S., Fiddes, J., Keller, M., Gruber, S., 2011. Scale-dependent measurement and analysis of ground surface temperature variability in alpine terrain. Cryosphere 5, 431-443.

Haeberli, W., 1973. Die Basis-Temperatur der winterlichen Schneedecke als moglicher Indikator fur die Verbreitung von Permafrost in den Alpen. Z. Gletscherk. Glazialgeol. 9, 221-227.

Haeberli, W., Patzelt, G., 1982. Permafrostkartierung im Gebiet HochebenkarBlockgletscher, Obergurgl, Oetztaler Alpen. Z. Gletscherk. Glazialgeol. 17, 127-150.

Ishikawa, M., 2003. Thermal regimes at the snow-ground interface and their implications for permafrost investigation. Geomorphology 52 (1), 105-120.

Jiménez, M., Rodríguez-Rodríguez, L., García-Ruiz, J.M., Domínguez-Cuesta, M.J., Farias, P., Valero-Garcés, B., Moreno, A., Rico, M., Valcárcel, M., 2013. A review of glacial geomorphology and chronology in northern Spain: timing and regional variability during the last glacial cycle. Geomorphology 196, 50-64.

Luetschg, M., Lehning, M., Haeberli, W., 2008. A sensitivity study of factors influencing warm/thin permafrost in the Swiss Alps. J. Glaciol. 54, 696-704.

Lugon, R., Delaloyé, R., Serrano, E., Reynard, E., Lambiel, C., González Trueba, J.., 2004. Permafrost and Little Ice Age relationships, Posets massif, Central Pyrenees, Spain. Permafr. Periglac. Process. 15, 207-220.

Marquínez, J., 1989. Mapa geológico de la Región del Cuera y los Picos de Europa. Trab. Geol. Univ. Oviedo 18 pp. 137-144.

Miotke, F.D., 1968. Karstmorphologische studien in der glazial-überformten Höhenstufe de Picos de Europa, Nordspanien. Selbtverlag der Geografischen Gessellschaft, Hannover.

Moreno, A., Valero-Garcés, B.L., Jiménez-Sánchez, M., Domínguez-Cuesta, M.J., Mata, M.P. Navas, A., González-Sampériz, P., Stoll, H., Farias, P., Morellón, M., Corella, J.P., Rico, M. 2010. The last deglaciation in the Picos de Europa National Park (Cantabrian Mountains, Northern Spain). J. Quat. Sci. 25 (7), 1076-1091.

Muñoz, J., 1982. Geografía Física. El relieve, el clima y las aguas, in: Quirós, F. (Dir.) Geografía de Asturias, Tomo I, Ayalga Ediciones, Salinas.

Oliva, M., Gómez Ortiz, A., 2012. Late Holocene environmental dynamics and climate variability in a Mediterranean high mountain environment (Sierra Nevada, Spain) inferred from lake sediments and historical sources. The Holocene 22 (8), 915-927.

Oliva, M., Schulte, L., Gómez Ortiz, A., 2009. Morphometry and Late Holocene activity of solifluction landforms in the Sierra Nevada (Southern Spain). Permafr. Periglac. Process. 20 (4), 369-382.

Oliva, M., Gómez-Ortiz, A., Salvador-Franch, F., Salvà-Catarineu, M., 2014a. Present-day solifluction processes in the semiarid range of Sierra Nevada (Spain). Arct. Antarct. Alp. Res. 46 (2), 73-78. 
Oliva, M., Gómez-Ortiz, A., Salvador-Franch, F., Salvà-Catarineu, M., Pereira, P., Geraldes, M., 2014b. Long term soil temperature dynamics in the Sierra Nevada, Spain. Geoderma 235-236, 170-181.

Oliva, M., Gómez-Ortiz, A., Salvador-Franch, F., Salvà-Catarineu, M., Ramos, M., Palacios, D., Tanarro, L., Pereira, P., Ruiz-Fernández, J., 2016a. Inexistence of permafrost at the top of Veleta peak (Sierra Nevada, Spain). Sci. Total Environ. 550, 484-494.

Oliva, M., Serrano, E., Gómez-Ortiz, A., González-Amuchastegui, M.J., Nieuwendam, A., Palacios, D., Pérez-Alberti, A., Pellitero-Ondicol, R., Ruiz-Fernández, J., Valcárcel, M. Vieira, G., Antoniades, D., 2016b. Spatial and temporal variability of periglaciation of the Iberian Peninsula. Quat. Sci. Rev. 137, 87-104.

Pellitero, R., 2012. Geomorfología, paleoambiente cuaternario y geodiversidad en el macizo de Fuentes Carrionas-Montaña Palentina PhD Thesis University of Valladolid, Valladolid, Spain.

Pisabarro, A., Serrano, E., González-Trueba, J.J., 2015. Régimen térmico de suelos del Macizo Central de Picos de Europa (España). Pirineos 170, e010. http://dx.doi.org/ 10.3989/Pirineos.2015.170003.

Riseborough, D., 2003. Thawing and freezing indices in the active layer. In: Phillips, M. Springman, S.M., Arenson, L.U. (Eds.), Proceedings of the 8th International Conference on Permafrost, pp. 953-958.

Rodríguez-Pérez, C., 1995. Estudio geomorfológico del Puerto de San Isidro. Ería 36, 63-87.

Rodríguez-Pérez, C., 2009. Geomorfología de la Montaña Astur-Leonesa entre los puertos de Ventana y de Somiedo PhD Thesis University of Oviedo, Spain.

Ruiz-Fernández, J., 2013. Las formas de modelado glaciar, periglaciar y fluviotorrencial del Macizo Occidental de los Picos de Europa (Cordillera Cantábrica) PhD Thesis University of Oviedo, Spain.

Ruiz-Fernández, J., 2015. Las formas de modelado glaciar, periglaciar y fluviotorrencial del Macizo Occidental de los Picos de Europa (Cordillera Cantábrica). B. Asoc. Geogr. Esp. 68 pp. $581-587$.

Ruiz-Fernández, J., Serrano, E., 2011. El modelado kárstico en el Macizo del Cornión. In: González, J.J., Serrano, E. (Eds.), Geomorfología del Macizo Occidental del Parque Nacional Picos de Europa. OAPN, Madrid, pp. 109-142.

Ruiz-Fernández, J., Poblete, M.A., Serrano-Muela, P., Martí-Bono, C., García-Ruiz, J.M., 2009. Morphometry of glacial cirques in the Cantabrian Range (Northwest Spain). Z. Geomorphol. N. F. 53, 47-68.

Ruiz-Fernández, J., Poblete, M.A., García, C., Gómez Ortiz, A., 2014. Características morfoclimáticas y procesos y formas periglaciares actuales en el Macizo Occidental de los Picos de Europa (Cordillera Cantábrica). In: Salvador, F., Oliva, M., Salvà, M. (Eds.), Avances, métodos y técnicas en el estudio del periglaciarismo. University of Barcelona, Barcelona, pp. 91-103.

Salvador-Franch, F., Oliva, M., Gómez Ortiz, A., Salvà-Catarineu, M., Valcárcel, M., Carrera Gómez, P., 2011. Valores térmicos del suelo en tres enclaves contrastados del sector de cumbres de Sierra Nevada (periodo 2006-2009). Criosferas, suelos congelados y cambio climático. Universidad de Santiago de Compostela, pp. 31-35.

Salvador-Franch, F., Salvà-Catarineu, M., Oliva, M., Gómez-Ortiz, A., 2015. Régimen térmico del suelo en un transecto altitudinal de alta montaña mediterránea con topografía contrastada (macizo del Puigpedrós, Pirineo oriental). Proceedings of the V Iberian Conference of the International Permafrost Association. University of Valladolid, Valladolid, Spain, Valladolid (Spain).

Santos, R., Marquínez, J., 2005. Las formas del lapiaz en el sector norte del Macizo del Cornión, Picos de Europa. Rev. C\&G 19 (1-2) pp. 35-47.

Santos-González, J., 2010. Glaciarismo y periglaciarismo en el Alto Sil, Provincia de León (Cordillera Cantábrica) PhD Thesis University of León, Spain.

Santos-González, J., González-Gutiérrez, R.B., Gómez-Villar, A., Redondo-Vega, J.M., 2009. Ground termal regime in the vicinity of relict rock glaciares (Cantabrian Mountains, NW Spain). Finisterra 87, 35-44.

Serrano, E González-Trueba, JJ, 2004. Morfodinámica periglaciar en el grupo Peña Vieja (Macizo Central de los Picos de Europa - Cantabria). Rev. C\&G 18 (3-4) pp. 73-88.

Serrano, E., Agudo, R., Delaloye, R., González-Trueba, J.J., 2001. Permafrost distribution in the Posets massif, Central Pyrenees. Nor. Geol. Tidsskr. 55, 245-252.

Serrano, E., San José, J.J., Agudo, C., 2006. Rock glacier dynamics in a marginal periglacial high mountain environment: flow, movement (1991-2000) and structure of the Argualas rock glacier. The Pyrenees. Geomorphology 74, 286-296.

Serrano, E., González-Trueba, J.J., San José, J.J., Del Río, L.M., 2011. Ice patch origin, evolution and dynamics in a temperate high mountain environment: the Jou Negro, Picos de Europa (NW Spain). Geogr. Ann. A 93, 57-70.

Serrano, E., González-Trueba, J.J., González-García, M., 2012. Mountain glaciation and paleoclimate reconstruction in the Picos de Europa (Iberian Peninsula, SW Europe). Quat. Res. 78, 303-314.

Serrano, E., González-Trueba, J.J., Pellitero, R., González-García, M., Gómez, M., 2013. Quaternary glacial evolution in the Cantabrian Mountains (Northern Spain). Geomorphology 196, 65-82.

Smart, P.L., 1986. Origin and development of glacio-karst closed depressions in the Picos de Europa, Spain. Z. Geomorphol. 30, 423-443.

Veit, H., Höfner, T., 1993. Permafrost, gelifluction and fluvial sediment transfer in the alpine/subnival ecotone, Central Alps, Austria: present, past and future. Z. Geomorphol. 92, 71-84.

Vieira, G., Mora, C., Ramos, M., 2003. Ground temperature regimes and geomorphological implications in a Mediterranean mountain (Serra da Estrela, Portugal). Geomorphology $52,57-72$.

Zhang, T., 2005. Influence of the seasonal snow cover on the ground thermal regime: An overview. Rev. Geophys. 43, RG4002. 